\title{
IMPROVING STUDENTS' READING COMPREHENSION BY USING SQ3R METHOD
}

\author{
Ahmad Bakhtiar \\ Program of Historical Education, Faculty of Education and Social Sciences, \\ University of Indraprasta PGRI \\ Jalan Nangka No. 58C Tanjung Barat, Jagakarsa, South Jakarta 12530 \\ ahmad_bakhtiar88@yahoo.com
}

\begin{abstract}
In this research, the writer used an action research. For collecting the data, the writer used test and observation. The data sources are the $11^{\text {th }}$ grade of MA. Mutmainah Bogor which consists of 38 students and an English Teacher as the observer. Cycle I consists of planning, action, observation and reflection. Cycle II added by the revision of cycle I. Based on the results of the research, in cycle I the percentage of students who achieved Minimum Accomplishment Criteria (MAC) 75 was 63\%. In other words, 24 students had achieved Minimum Accomplishment Criteria (MAC), while 14 students had not reached MAC. In cycle II, all of students have reached Minimum Accomplishment Criteria (MAC). The result showed, in cycle II all of the students could comprehend the text and determine the main idea and reached Minimum Accomplishment Criteria (MAC) in reading it is 75 . Thus, the hypothesis in this research is acceptable. It means, there is a significant improving in using SQ3R to increase the students' reading comprehension at the $11^{\text {th }}$ grade of MA. Mutmainah Bogor. Therefore, the research was discontinued on the second cycle.
\end{abstract}

Key Words: classroom action research, SQ3R, students' reading comprehension

\section{ABSTRAK}

Dalam penelitian ini, penulis menggunakan penelitian tindakan, sedangkan teknik dan pengumpulan data menggunakan tes dan observasi. Sumber data penelitian siswa kelas 11 Madrasah Aliyah Mutmainah Bogor berjumlah 38 siswa. Penelitian ini menggunakan penelitian tindakan.Siklus I : perencanaan, tindakan, pengamatan, dan refleksi. Siklus II ditambahkan hasil perbaikan dari siklus I. Berdasarkan hasil penelitian, pada siklus I persentase siswa yang memperoleh KKM 75 yaitu $63 \%$. Dengan kata lain, 24 siswa telah memenuhi KKM, sedangkan sisanya 14 siswa belum mencapai KKM. Pada siklus II semua siswa (100\%) telah mencapai KKM. Hasil penelitian menunjukan bahwa setelah siklus II semua siswa sudah mampu memahami dan menetukan ide pokok suatu teks dengan baik dan memperoleh nilai reading di atas KKM yaitu 75. Dengan demikian, hipotesis penelitian ini diterima, artinya terdapat peningkatan yang positif penggunaan metode SQ3R terhadap pemahaman bacaan siswa kelas XI IPS I MA Mutmainah Bogor. Oleh karena itu, penelitian dihentikan pada siklus II.Maka bisa diberikan kesimpulan: metode SQ3R mampu meningkatkan kemampuan reading comprehension siswa.

Kata kunci: penelitian tindakan kelas, SQ3R, pemahaman bacaan siswa 


\section{INTRODUCTION}

The ability of reading is another capability that must be achieved as the goals of teaching English besides listening, speaking, and writing. Reading gives a great influence for our life because we are able to find knowledges that are written in many books. But it is very complicated or complex, because it is an activity carried out under the cooperation of several skills, as observing, understanding, and thinking that can support these skills, and it also depends on the language skills and the level of reasoning. The aim of reading comprehension is to understand or to comprehend the message contained in a text.

Based on pre-observation done by the writer, teaching reading process at the eleventh grade students have some obstacles. They are; the students feel difficult in comprehending the text as whole. For example, in answering the questions related to the text and finding the main idea of each paragraph in the text. It is because the learning method used in teaching reading was not oriented to the students, it means the students tend to be passive in reading learning process. In other words, the learning method must involve the students in learning process. These problems are related to the research on reading comprehension has been done previously by Ginanjar (2011:3), he concludes that, "One of the difficulties in reading text is determaining the main idea. This case can make the students less confident, and surrender before catching the main idea". It means that one of the students' difficulties in reading text is in determining the main idea in a paragraph of the text. This problem can make students less confident and easy to give up in finding the main idea of a paragraph in a text.
These anxieties are one of the students' troubles in reading learning process and requires the attention of an interested parties, especially for the teachers.

SQ3R is a strategy used for studying of the texts or documents, firstly by understanding the text, and build a mental framework into the facts that can be applied. This method was introduced firstly by Francis $P$. Robinson from the University of Ohio, USA, in 1941. The results of students' learning by using SQ3R can be expected to be more satisfied because SQ3R method can make students to be active readers and focused directly to the essence or the contents of implicit and explicit subject in the text.

In this method the first step is to read on the surface of the all items in the text reading and find out how the text is organized (Survey), and then compiling the questions will be answered from the text (Question), started by reading the material with the objectives and questions that had been developed (read), then students recall the information what is learned and spoken, or make a small note of the important points to remember more (Recite), and finally review the material read before to ensure and to remember what was read (Review).

There are some steps of SQ3R method, according to Tarigan (2008: 35),

1) Survey

Siswa membaca topik utama, judul, kalimat permulaan dan ringkasan suatu bab.

2) Question

Siswa mengajukan pertanyaan pada diri sendiri untuk setiap pasal yang ada pada bacaan.

3) Read

Siswa membaca bacaan untuk menemukan jawaban atas pertanyaan mereka. 
4) Recite

Setelah selesai membaca, siswa mencoba mengingat kembali apa yang telah dibaca dan meneliti segala apa yang telah diperoleh dan membuat catatan tentang isi bacaan.

5) Review

Siswa membaca kembali catatan tentang isi bacaan yang telah dibuat. Dan jika diperlukan, ulang kembali seluruh isi bacaan.

It means the steps of SQ3R are:

1) Survey

Students begin by reading the main topic, title, headings and chapter summary.

2) Question

The students make questions based on the text.

3) Read

The students read the text actively and try to find the answer of the previous questions.

4) Recite

The students recall the information learnt and make a brief note of the contents of the text.

5) Review

The Students re-read the brief note that has been created. If it is necessary, repeat the entire contents of the text.

It can be concluded that SQ3R method has specific stages in comprehending reading text that applied in reading process, they are; survey, question, read, recite and review.

Based on the reasons above, the writer conducts the research entitled, 'Improving Students' Reading Comprehension by Using SQ3R Method (An Action Research at the 11

th Grade of MA Mutmainnah Bogor)."

\section{METHOD}

In this research, the writer uses action research method. As said by Arikunto (2006:90) that the action research is the solving problem strategies which takes the benefits of a real action in the form of development process "tried by running" in detecting and solving the problem.

To get the data needed in this research, the writer uses test and observation. Test is an instrument to measure something. Observation is an investigating process appeared on research object.

The research instrument chosen by the writer is test (objective test) and observation sheet in the checklist item form.

a. Data and Data Resources

The action research has two kinds of data that must be analyzed by the researcher. They are the quantitative data are obtained through test given by the writer in each cycle and the qualitative data are observation results about the process in teaching learning.

The data sources of this research are the $11^{\text {th }}$ grade students of MA. Mutmainnah Bogor consist of 38 students and an observer, he is an English teacher at MA Mutmainnah Bogor.

b. Research Design

In action research, there are four stages, they are planning, action, observation, and reflection. In conducting this research, the writer uses the action research model of Kemmis and Mc Tagart as quoted by Arikunto (2010:132), 


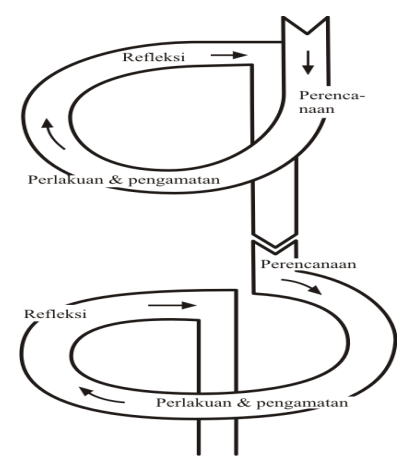

Figure 1

Model of Action Research

d. The Research Steps

The steps of research are taken by the writer, as said by Sanjaya (2017), as follows;

1. Observing previous reading comprehension.

2. Planning the action, constructing the lesson plan.

3. Implementing the action.

4. Observing the implementation of treatment.

5. Giving the reflection for the results of the observation.

6. Analyzing the results and classified them quantitatively.

7. Constructing the lesson plan.

8. Implementing the action.

9. Observing the implementaion of treatment.

10. Observing the implementaion of treatment.

11. Analyzing the results and classified them quantitatively.

Teaching learning process of reading using SQ3R method is successful if all of the students' scores $100 \%$ reach equal or over the MAC (Minimum Accomplishment Criteria) 75.

\section{RESULTS AND DISCUSSION}

After applying SQ3R method in teaching reading comprehension, the result shows that there is an improvement of students reading comprehension. It is proven from the progress of students' reading achievement. From the cycle I, there are 24 students or $63 \%$ who achieve over Minimum Accomplishment Criteria (MAC) 75. In the cycle II, there are 38 students or $100 \%$ who have achieve over Minimum Accomplishment Criteria (MAC) 75.

There is an improvement of students' reading comprehension using SQ3R method. The writer gets the data both from the test result and the observation result from the cycle I and II. Based on the research results above, the writer knows some problems found by the readers in reading comprehension. Most of them are confused to determain the main idea and applicating SQ3R method in reading text. All of the students achieve Minimum Accomplisment Criteria (MAC).

Based on the research result, it is clearly that SQ3R implementation method can improve the reading comprehension of the students. By using this method, students begin by reading the main topic, title, headings and chapter summary (survey), make questions based on the text (question), read the text actively and try to find the answer of the previous questions (read), recall the information learnt and rewrite the contents of the text (recite), students re-read the brief note that has been created. If it is necessary, repeat the entire contents of the text.

As said by Syah (2009) that the results of students' learning by using SQ3R can be expected to be more satisfactory because SQ3R method can make students to be an active reader and focused directly to the essence of implicit and explicit contents of the subject in the text. 
According to Akhmad and
Mulyati (1997), "Metode ini memungkinkan para siswa untuk belajar secara sitematis dengan bantuan langkah-langkah kerja yang tepat dan efisien." It means, that through the use of SQ3R, students can improve their reading efficiency. In teaching reading process, SQ3R method provides students with a systematic and efficient method. In this way, students are expected to be an active reader.

Based on the data above, the writer concludes that the 11 th grade students of MA. Mutmainnah Bogor get development in their English learning. The writer assumes that the English teacher can use SQ3R method for increasing reading comprehension of the students.

\section{CONCLUSION}

To conduct this research, the writer used the clasroom action research. There are four stages in the implementation of the action research, they are planning, action, observation, and reflection. The aim of the research is to find out the improvement of students' reading comprehension using SQ3R method. The research is successful if all students can reach $K K M \geq 75$. The result of the research are presented as follows:

\section{Cycle 1}

In the end of the learning process at the cycle 1 , the teacher gave a post test to measure students' reading comprehension. The result of test will be used as the data to determine need or no cycle II is conducted.

Based on the data the total numbers of the students achieving KKM (75) are 24 from 38 students. It means that there are 14 students who do not get the score over $K K M$. Thus, the percentage of the students achieving $K K M$ is as follows:

$$
\begin{aligned}
& \mathrm{P}=\frac{\mathrm{n}}{\mathrm{N}} \times 100 \% \\
& \mathrm{P}=\frac{24}{38} \times 100 \% \\
& \mathrm{P}=63 \%
\end{aligned}
$$

The Result of the reflection at the cycle I shows that teacher role in learning process should be revised. The revision should be done without ignoring the elements of learning process.

\section{Cycle II}

The presentation of students' Achievement in getting $K K M$ at the cycle II can be shown in the result below:

$$
\begin{aligned}
\mathrm{P} & =\frac{\mathrm{n}}{\mathrm{N}} \times 100 \% \\
\mathrm{P} & =\frac{38}{38} \times 100 \% \\
\mathrm{P} & =100 \%
\end{aligned}
$$

Based on the result of the action process, the writer got the significant progress. In cycle I there are just 24 students who reach $K K M$ or $63 \%$ from all students. In cycle II all of students have reached $K K M$ or the percentage reach $100 \%$. It means the action hypothesis of this research "using SQ3R method can improve the students' reading comprehension at the eleventh grade of $M A$ Mutmainah Bogor " is accepted. Based on the result, the writer and the observer made decision that the research should be stopped until cycle II.

After analyzing the data, it concluded that SQ3R method has positive influence on the students' reading comprehension. By using SQ3R method, the students' reading activity becomes more attractive and interesting, and teaching learning process is not boring and monotonous. In cycle I there are $63 \%$ students who reach MAC. Meanwhile, at the cycle II all of the students have reached MAC. It 
indicates that the students' learning accomplishment is successful, and it doesn't need to be continued to the cycle III.

It means that SQ3R method is very useful and appropriately method to use in teaching reading. SQ3R is proven can increase reading comprehension of the students.

Finally, the writer concludes from the research result shows that the use of SQ3R method in teaching reading can increase reading comprehension of the students effectively. It has been proven from the test and the observation result.

\section{REFERENCES}

Akhmad, S. H., \& Mulyati, Y. (1997). Membaca 2. Jakarta: Departemen Pendidikan dan Kebudayaan. Unpublishing Company.

Arikunto, S. (2006). Prosedur Penelitian. (Edisi Revisi). Jakarta: Rineka Cipta.
(2010). Prosedur Penelitian (Suatu Pendekatan Praktik). Jakarta: Rineka Cipta.

Ginanjar, L. (2011). Improving the Students' Reading Comprehension by Using PQ4R Technique. (A Classroom Action Research at the Eight Grade of SMPN 1 Panumbangan Ciamis). Tasikmalaya: Unpublished.

Sanjaya, R. E. (2017). Improving vocabulary ability by using comic. Scope: Journal of English Language Teaching.

Syah, M. (2009). Psikologi Pendidikan Dengan Pendekatan Baru. Bandung: Remaja Rosda Karya.

Tarigan, H. G. (2008). Membaca Sebagai Suatu Keterampilan Berbahasa. Bandung: Angkasa. 